\title{
Глазами ,другого" (заметки о прозе Е.Г. Эткинда)
}

\begin{abstract}
Krivonos Vladislav, Glazami „drugogo” (zamietki o prozie J.G. Etkinda) (Through the Eyes „of the Other” [Notes on E.G. Etkind's Prose]). „Poznańskie Studia Slawistyczne” 6. Poznań 2014. Publishing House Science and Innovate, pp. 157-168. ISBN 978-83-63795-51-1. ISSN 2084-3011.

In the article E.G. Etkind's prose is discussed from the point of view of its place and role in the dissident movement in the Soviet Russia. The particular attention is paid of Etkind's ideological differences with the political regime and of the Jewish theme which was very important to his selfconsciousness. The article shows how Etkind's position defined the angle of the narrative in his prose, and especially his view of the events.
\end{abstract}

Keywords: Etkind; dissidents; human rights activist; „other”; emigration; anti-Semitism; the Jewish theme; Vladislav Krivonos; Volga Region State Socio-Humanitarian Academy; Samara-Russia

Ефим Григорьевич Эткинд формально не принадлежал к диссидентскому движению и не был диссидентом „в полном смысле слова” (Долинин 2000: 273). Но он тяготел к психологическому типу диссидента, чье поведение требовало прежде всего „отрешенности от личных стремлений, жертвенности" (Алексеева 2012: 234). Неверно было бы, однако, представлять Эткинда внутренним эмигрантом, уклонявшимся от какого-либо сотрудничества с режимом: он был профессором вуза, исследователем, переводчиком, членом Союза писателей СССР, публиковался в подцензурных журналах и сборниках. За свои убеждения он предпочитал бороться легально, выступив свидетелем защиты на процессе Иосифа Бродского. В то же время он участвовал в подготовке самиздатского собрания сочинений Иосифа Бродского, активно поддерживал Солженицына, с которым был в дружбе более десяти лет. Эмиграция, к которой в конце концов принудили Эткинда, изначально не входила в его планы; смысл своей деятельности, 
правозащитной по содержанию, но без прямой конфронтации с государственной системой, он видел в изменении условий существования в стране проживания.

Важным пунктом, определившим идеологические расхождения Эткинда с властью и критическое к ней отношение, вообще психологические механизмы его поведения, было его еврейское происхождение и связанные с ним травматические переживания, отложившиеся в памяти. Поэтому обращение к еврейской теме в его прозе, где она занимает исключительно важное место, кажется отнюдь не случайным. Эткинд, при всем своем „бескомпромиссном интернационализме” (Эткинд 2001: 260), никогда не забывал о своем еврействе, благо окружающая действительность то и дело ему об этом напоминала. А вот в роли „полезного еврея”, которому позволили бы, как пел Александр Галич, украсить „лапсердак аксельбантом”, вообразить его было совершенно невозможно.

В Записках незаговориика, впервые вышедших в Лондоне в 1977 году, Эткинд вспоминает о заседании бюро Ленинградского обкома, где обсуждалась „диверсия”, обнаруженная в его вступительной статье к сборнику Мастера русского стихотворного перевода:

Даже сейчас, воспроизводя мой собственный ход мысли, я стыжусь за себя: почему же я, даже не говоря этого вслух, позволил себе согласиться с тем, что Мандельштам, Пастернак, Маршак, Эренбург - всего лишь евреи? Они еще и деятели русской культуры, они русские писатели, как и я, будто бы сколачивающий из них особую „группу” еврейских переводчиков. Все мы - евреи по крови, евреи для расистов, для антисемитов, для дикарей (Эткинд 2001: 125).

Государственный и бытовой антисемитизм глубоко оскорбляет Эткинда, как бы слабо ни ощущал он в себе собственно еврейское начало: „Автор этих строк - еврей «по крови» но ни язык, ни культура, ни образ мыслей не отделяет его от России Пушкина и Толстого, Блока и Мандельштама" (Эткинд 2001: 259). Он видит себя не просто русским евреем, а носителем комплекса черт, присущих исторически сложившемуся типу русского интеллигента. Такого рода русифицированность была свойственна не персонально Эткинду, но вообще значительной части советских евреев. И дело было не только в том, что окружающая реальность, сугубо отрицательно окрашивая для них этническую идентификацию, в качестве наиболее приемлемой стратегии 
поведения предлагала путь ассимиляции и аккультурации (Фурман 1995: 77-79; Юхнёва 1999: 172). Главным и определяющим было твердое сознание внутренней причастности к русской культуре.

Одной из причин преследования Эткинда со стороны властей было написанное им Открытое письмо молодым евреям, стремящимся в эмигращию: „В 1974 году меня уволили из Института им. Герцена, обвинив, помимо прочего, в открытом письме молодым евреям, где я призывал их не уезжать, а бороться за равноправие и свободу дома, в пределах своего языка и своей культуры” (Эткинд 2001: 460).

В Записках незаговоршика Эткинд воспроизводит возможный ход мыслей профессора Н.М. Александрова, своего коллеги и давнего знакомого, которого ректор побуждает выступить с осуждением автора „воззвания к еврейской молодежи”:

К чему же он ее призывает? Уезжать в Израиль? Воевать с арабами? Нет, оказывается (...) призывал Эткинд молодежь „не покидать Советского Союза” (...). Молодец, Эткинд, правильно призывал, давно пора сказать этим юношам и девушкам, что, уезжая в Израиль, они покидают свою страну и свою культуру (Эткинд 2001: 59).

А в Барселонской прозе цитирует и комментирует заявление поэта Михаила Дудина на заседании секретариата Союза писателей, что

в письме Эткинда молодым евреям ,самое отвратительное - национализм, от него пол-локтя до фашизма. Этот сионизм лезет из каждой строки”. Явная нелепость: в письме я убеждал молодых евреев не уезжать в Израиль, не стремиться к чужой свободе, а бороться за свою собственную у себя дома. Такую позицию можно было назвать антисоветской, но никак не сионистской - ведь она открыто полемична по отношению к сионизму (Эткинд 2001: 439).

Призыв к молодым евреям не эмигрировать, то есть не репатриироваться в Израиль (другой возможности покинуть страну у евреев просто и не было: советской идеократией не признавались зафиксированные во „Всеобщей декларации прав человека” неотчуждаемые права и свободы человека, в том числе право каждого покидать любую страну, включая свою собственную, и возвращаться в свою страну), исходил от одного из поколения ассимилированных „отцов”, избравших путь слияния с русской культурной почвой. Этот призыв раздался в то время, когда в среде еврейской молодежи заметно усилились 
эмиграционные настроения (Дашевский et al. 1989: 461). Те из поколения „детей”, для кого значимой становилась собственная еврейская идентичность, стремились уехать на историческую родину, чтобы реализовать там свои национально-культурные и национально-религиозные устремления. Так вновь повторялась в истории российских евреев ситуация конфликта ассимилированных „отцов” и „детей”, не испытывавших чувства психологической раздвоенности и не принимавших ассимиляцию как свой путь (Проскурина 1992: 236-238). У них было иное, чем у поколения „отцов”, видение дома.

Письмо Эткинда, включенное властью в список его главных прегрешений, было, несомненно, продиктовано благими соображениями. Но так получалось, что он и его предполагаемая аудитория говорили на разных языках. У правозащитного и у еврейского эмиграционного движений были разные цели и соответственно разная логика поведения (Алексеева 2012: 123). Автор письма, и в позднем комментарии не освободившийся от мифического представления о сионизме, оставляет за скобками тоску „детей” по исторической родине, их отказ смириться с государственным антисемитизмом, с национальной и культурной дискриминацией, суть их борьбы за право быть евреями.

Эткинд предпочитает говорить не о еврейском уходе, а о вынужденной эмиграции и насильственном изгнании участников русского культурного процесса: „Впрочем, делить людей на евреев и неевреев нелепо; уезжают деятели русской культуры, кем бы они ни числились в паспорте” (Эткинд 2001: 258). Но и к нему приходит ясное понимание причин, толкающих в эмиграцию еврейскую молодежь: „Уезжают евреи - те, кто сами считают себя евреями и видят свой жизненный долг в строительстве государства Израиль” (Эткннд 2001: 260). Хотя к отъезду побуждало евреев не только обостренное национальное самосознание:

Уезжают и другие: те, кто верит в свои духовные силы и знает, что на родине эти силы развернуть не удастся. Отделы кадров на работу их не берут. В аспирантуру их проваливают, хотя заведомо ясно, что они созданы для научных исследований. На конгрессы не пускают. Их книги стараются не публиковать (,звук чуждый” - на переплете!) (Эткинд 2001: 262).

Как ни сопротивлялся отъезду сам Эткинд, изгнанный с работы и лишенный ученых степеней и званий, пришлось и ему выехать по 
израильской визе, поскольку наступил момент, когда оставаться было „и гибельно, и бесполезно” (Эткинд 2001: 263). Хотя Эткинд и называет себя ,агностиком, очень далеким от всякого сионизма, но для своих гонителей он был, как ему пришлось убедиться, прежде всего евреем по крови, по фамилии, по прирожденной чуждости” (Эткинд 2001: 447). Между тем его личным выбором была верность русской культуре и стране, где он к этой культуре, ставшей для него своей, навсегда приобщился. Из Вены Эткинд отправляется не в Израиль, а в Париж, чтобы продолжить и свою профессиональную деятельность, и свое служение русской культуре.

Во Вступлении к Запискам незаговорщика содержится важное для его нравственной позиции признание:

Я мог позволить себе рассказать многое, чему был свидетелем и чего оказался жертвой. И все же я смотрю на события, происходившие в Советском Союзе, не извне, а изнутри, и рассказываю обо всем не для того, чтобы обвинять мою страну. Она моя, и другой у меня нет (Эткинд 2001: 19).

И все же только взгляд изнутри не мог не ограничивать авторский кругозор. В Барселонской прозе подобный взгляд, корректируемый и травмой вынужденной эмиграции, оборачивается порой явным прекраснодушием: „Понять Дудина значит понять гнусную и прекрасную эпоху, в которую мы с ним жили” (Эткинд 2001: 441). То, что эпоха осуществленной утопии, эпоха массового террора и концлагерей названа „гнусной”, понятно и не требует комментария. Но была ли она „прекрасной”?

Самоотождествление со „страной” (без уточнения, имеется ли в виду географическая территория, культурное пространство, историософский образ или правящий режим), которую он продолжал считать „моей”, вызывало у Эткинда вполне объяснимое чувство ностальгии. Но психологически наиболее адекватным ситуации, в которой он оказался, было испытанное им чувство стыда; позже он напишет, что „испытывал стыд за Россию” (Эткинд 2001: 452). Стыд не только за тех коллег, кто принял участие в травле, за малодушие и равнодушие тех знакомых, кто отвернулся в час постигшей его беды, но и за свою „страну”.

В Барселонской прозе Эткинд тепло вспоминает о друзьях своей юности, с которыми его сближала вера в интернационалистскую 
утопию; имеется в виду идеологический миф, „на котором воспитывались дети и юношество в 20-е и особенно в 30-е годы” (Маркищ 1997: 203). Ср.: „Мы выросли, испытывая великолепное презрение к национальным предрассудкам" (Эткинд 2001: 427). Для Эткинда и его круга главным было чувство дружеской общности, исключавшей национальную обособленность или национальное высокомерие: среди его друзей „были евреи, но разве еврейство кого-нибудь тревожило или даже просто интересовало? В нашей компании евреев были и русские... но и они не ощущали различий - евреи для них не были другими” (Эткинд 2001: 427). Правда, у евреев и не было возможности почувствовать и ощутить себя евреями: „Советские люди в тридцатые годы не разделялись на национальные группы” (Эткинд 2001: 428). Евреям следовало быть такими, как все, и забыть о своем еврействе. Как напоминают историки, именно в это время как раз усиливается „процесс этноцида советских евреев, то есть лишения их любых форм национальной культурной и общественной жизни" (Дашевский et al. 1989: 457).

Показной интернационализм официальной идеологии табуировал тот факт, что еврей в тоталитарном государстве, каким бы ни был его статус, переставал быть евреем: „Гиллельс, Ойстрах, Гольдштейн поощрялись партией, несмотря на их «неблагозвучные» фамилии: они поддерживали миф о советском социализме как земле обетованной для культуры” (Эткинд 2001: 308). Паспортные знаки национальной принадлежности именитых соплеменников сами по себе мало что значили для „еврейских мальчиков” (Эткинд 2001: 427). Ведь в пору их „студенчества еврейские фамилии советско-российских интеллигентов были знамениты во всем мире (...). Меньше всего мы воспринимали их как евреев; для нас все они были гордостью советской страны, российской культуры” (Эткинд 2001: 428).

Подобного рода восприятие отличало не только Эткинда и его друзей, но вообще целое поколение русско-еврейских интеллектуалов, хоть и сознававших, что „для многих окружающих они, чем бы ни занимались, оставались евреями”, однако настаивавших „на том, что их национальное происхождение - малозначимая деталь, которая почти ничего в их жизни не определяла" (Эпштейн 2010: 86). Так формировалась характерная двойственность национального самосознания 
советских евреев, принадлежавших к интеллектуальной прослойке общества, привязанных к России и к русской культуре и сохранявших „при этом еврейскую самоидентификацию” (Гензелева 1999: 12).

Познакомившись с дневниками Виктора Клемперера, немецкого ученого-филолога, еврея по происхождению, протестанта по вероисповеданию и немца по мироощущению, в деталях описавшего, что значило быть евреем в нацистской Германии, Эткинд не случайно почувствовал некую общность судьбы:

Его в Германии, меня в советской России преследовали, травили, изгоняли за еврейство. Разница в том, что его называли евреем, жидом, заставляли носить желтую звезду на рукаве, вешать над звонком в квартире тот же „моген-давид”; я никогда ни от кого слова „еврей” не слышал - оно заменялось разными синонимами, вроде „космополит”, „сионист”, „беспачпортный бродяга”, ,антипатриот” (Эткинд 2001: 447).

Общность судьбы обнаруживалась и в том, что каждый из них „По-своему настаивал на принадлежности к окружавшей его культуре” (Эткинд 2001: 460). Как Клемперер, испытывая после 1933 года острые сомнения в собственной немецкости, продолжал считать себя частью немецкого народа, так Эткинд, по его словам, „утверждал то же самое относительно моей приверженности русской культуре” (Эткинд 2001: 461). Эту свою приверженность не только культуре, но и стране, которую его заставили покинуть, он подтверждает цитатой из авторского вступления к Запискам незаговорщика. Так создается в прозе Эткинда автобиографический образ русского еврея, не тяготящегося собственной ассимилированностью и искренне чувствующего себя своим в русской культуре. Тем понятнее его разочарование и обида, когда он вдруг открывал для себя, что далеко не все, с кем он сталкивался в жизни и кто входил даже в близкий к нему круг, видели в нем своего.

В книге Эткинда Барселонская проза есть автобиографическая новелла Другой. Автор передает в ней свою реакцию на комментарий Солженицына, поведавшего, как весной 1972 года „риском и находчивостью двух евреев”, одним из которых был Эткинд, он, „русский писатель в русское памятное время при «русских вождях»", попал в Таврический дворец и смог посмотреть ,зал заседаний Думы и места февральского бурления” (Эткинд 2001: 433). 
Что же так взволновало Эткинда в этом, казалось бы, вполне благоприятном по отношению к героям рассказа признании? „Оказывается, я всегда был для него - другой. Он - русский писатель, а Давид Прицкер и Ефим Эткинд - два еврея, помогавшие ему. Мы, посторонние, чужие, свидетели, помогли ему - коренному участнику, русскому по крови, своему" (Эткинд 2001: 433).

Так больно задевшая Эткинда фраза была воспринята им как словесно-психологический жест, обнаживший неприятно поразившее его отношение к нему и к его другу, в которых писатель увидел всего лишь евреев. На первый взгляд, в отношении Солженицына к „двум евреям” очевидна не столько настороженная отчужденность, сколько благожелательная отстраненность, вовсе не исключающая признательности тем, кто помогал ему осуществить миссию русского писателя. Можно даже заметить, что характерная для фольклорного образа еврея высокая степень чужести (Белова 2002: 81) сменилась у Солженицына не просто нейтральным в смысле оценки, но вполне позитивным признаком другого. А дело все в том, что в национально-историческом мифе писателя, резко акцентировавшего собственную русскость (в противовес советской ментальности „русских вождей”), евреям, как с горестью обнаружил Эткинд, было отведено место посторонних, хотя из чужих они превратились у Солженицына в других.

Но Эткинда, находившегося долгие годы в дружбе с Солженицыным, ранит совсем не эта метаморфоза. Он ведь вовсе не считал себя другим, на что имел, как искренне полагал, полное право. И потому в неожиданном определении „два еврея” увидел фигуру отторжения:

Солженицын не понял - да и не может, вероятно, понять, - что само по себе представление о том, что еврей - другой, посторонний, свидетель, а не участник по причине крови, что уже это представление является проявлением антисемитизма. (...) Нет, не два еврея помогали русскому писателю. Странно, что Солженицын не увидел солидарности тех, кто причастен к культуре, не оценил независимой от состава крови потребности интеллигенции к взаимоподдержке (Эткинд 2001: 434-435).

Действительно ли в комментарии Солженицына проявляется расовый антисемитизм или же не имеющая ксенофобской подкладки убежденность, что евреи в России неизбежно остаются именно и только евреями? Но Эткинд ведь как раз настаивает на своей принадлежности к русской культуре, что более значимо для его самосознания, чем 
национальное происхождение. Евреем же он сознает себя (по крайней мере, в ситуации, когда ему напоминают о составе крови) только в ответ на антисемитизм, аномальность которого ясна ему и как еврею по происхождению, и как русскому интеллигенту по мироощущению.

Отсюда и резкое неприятие им солженицынской фразы. Ведь другим (или даже чужим) он привык быть только для власти, приближавшей к себе лишь особо ценных евреев, кто обнаруживал готовность, подобно Я.Е. Эльсбергу, теоретику и историку литературы по профессии и „подлецу патологическому" (Эткинд 2001: 123) по характеру, или А.Л. Дымшицу, такого же рода спецу по литературе и карьеристу по убеждению, неуклонно продвигавшемуся „в рядах номенклатуры” (Эткинд 2001: 395), обслуживать аппарат репрессий и прислуживать режиму. (В скобках необходимо сказать и о том, что в осуждении Эткинда приняли участие - кто из страха, а кто и из идейной солидарности с гонителями - и некоторые коллеги-евреи, что, видно, призвано было закамуфлировать антисемитский характер травли.) Вот почему так поразившее и удивившее его определение „два еврея” показалось Эткинду проявлением антисемитизма. Тем более неожиданным, что речь не просто о выдающемся писателе, но о непримиримом борце с тоталитарным строем - строем, намеренно внедрявшем антисемитские предрассудки и стереотипы в сознание людей.

Критика власти Солженицыным за ее „недостаточную «русскость»”, обращенная прежде всего к среде „сторонников и сочувствующих", не разделявших, как правило, „либеральные идеи правозащитников" (Козлов 2002: 76), выдает в нем идеолога-почвенника, не просто близкого к движению русских националистов, но игравшего основную роль в разработке „русско-православного мировоззрения” (Алексеева 2012: 362). Своим замечанием Солженицын поставил под вопрос общую принадлежность его и Эткинда к месту, называемому исторической Россией; себе он отвел роль хозяина, Эткинду же определил роль гостя, что не могло не вызвать у последнего не самые приятные воспоминания.

В мемуарной прозе Эткинда антисемитизм осмысляется и как форма массового психоза, нагнетавшегося официальной пропагандой, запугивавшей население происками „космополитов” и кознями „врачей-убийц”, и как способ самоактуализации режима, эволюционировавшего в сторону идеологии „крови и почвы”. Отсюда особый интерес 
автора к процессу отторжения советских евреев и их превращения в других и в чужих, резко разрушавшему иллюзии ассимиляции.

Начало этого процесса Эткинд датирует 1939 годом, временем сближения сталинского Советского Союза с гитлеровской Германией, когда „проявились первые (фактические) запреты и ограничения для носителей еврейских фамилий: дипломатия (с нее началось), физика, военная техника, высокие армейские должности" (Эткинд 2001: 428). Следующим этапом были годы войны, которая „велась за чисто российские ценности, за православную веру, за Святую Русь" (Эткинд 2001: 429). Затем пришла пора массовой истерии 1948-1953 годов, вылившейся в настоящий антисемитский террор (Эткинд 2001: 430).

И далее в советской истории, по свидетельству Эткинда, видоизменялись лишь формы и методы государственного антисемитизма, но „антисемитские настроения” никогда не переставали „мутным потоком” разливаться „в нашей стране” (Эткинд 2001: 259). Они могли приобретать то уголовную окраску, когда судили в 1964 году, обвинив в тунеядстве, Иосифа Бродского (Эткинд 2001: 39), то политическую, как это было в 1968 году, когда „еврейский вопрос встал особенно остро”, так как официальная пропаганда именно „сионистов” объявила зачинщиками „пражской ереси” (Эткинд 2001: 127), то идеологическую, как в 1974 году, когда стряпали „дело” самого Эткинда.

Обозначенный им процесс отторжения определил этапные моменты его собственной биографической истории, советский период которой, ознаменованный увольнением в 1949 году из ленинградского Института иностранных языков „с доцентской должности - «за ошибки космополитического характера»” (Эткинд 2001: 374), завершился через двадцать пять лет после этого достопамятного события изгнанием не только с профессорской теперь должности, но и вообще из страны.

Уже во время войны, по наблюдениям мемуариста, евреи стали другими, поскольку не могли быть носителями русского патриотизма; после войны они оказались не просто другими, но „единоверцами и единоплеменниками «врагов нашей страны, нашей партии, наших идей»” (Эткинд 2001: 430). Историческую драму советского еврейства Эткинд объясняет искусственно создаваемым отчуждением „от «коренного населения» России”, с горечью констатируя, что представление о чуждости евреев сменяется „убеждением в их враждебности”. 
Таковы рассмотренные автором „две стадии антисемитизма; первая чревата второй” (Эткинд 2001: 434).

Между тем каждая из этих стадий, как показано в его прозе, была чревата возрождением старых антисемитских мифов и их трансформацией в идеологемы, пригодные для обоснования и оправдания практики дискриминации и этноцида. Другому, как подсказывал Эткинду его опыт (принадлежа к русской культуре, он все равно оставался евреем и нес бремя еврейской судьбы), всегда легче было вновь превратиться в чужого, чем стать своим. Именно этого, на его взгляд, почему-то и не понял Солженицын, творя свой национально-исторический миф, где евреям была отведена роль других.

Возможно, что писатель и не вкладывал в свои слова какого-либо негативного смысла и что Эткинд действительно оказался „пристрастно суров к Солженицыну" (Лурье 2001: 479). Но вряд ли Эткинд мог забыть о том трагическом времени, когда, после начала травли „космополитов”, вина каждого из которых заключалась в том, „что он - еврей” (Эткинд 2001: 136), и ареста Г.А. Гуковского, и он „каждую ночь ждал обыска и ареста” (Эткинд 2001: 457). Времени, когда ,даже слово «еврей» произносилось шепотом, как что-то непристойное или постыдное" (Маркиш 1997: 218). Неуместное, на взгляд Эткинда, напоминание русского писателя об этническом происхождении тех, кто взялся ему помогать, говорило не только о странной аберрации нравственного зрения (выходило, что для Солженицына он был не русским ученым, а всего лишь евреем), но и об утрате исторической памяти.

Василий Гроссман, автор романа Жизнь и судьба, был назван исследователем его творчества „писателем еврейской судьбы”: „Я думаю, нельзя сомневаться, что этот роман не был бы написан, не перенеси Гроссман ударов судьбы, которые выпали ему именно как еврею" (Маркиш 1997: 99). Неукорененность русского писателя Гроссмана в еврейской цивилизации не отменяла наличие у него обостренного чувства национального достоинства. В высшей степени оно было свойственно и Эткинду. Сравнивая свою судьбу с судьбой Виктора Клемперера (знаменательным кажется название его очерка о дневниках немецкого ученого: Две еврейские судьбы), он имел все основания видеть в себе и русского ученого, и носителя еврейской судьбы, не считающего для себя нравственно возможным от нее уклониться. Подобная 
исторически мотивированная позиция определила и его место в оппозиционной среде, и избранный им ракурс повествования. Если не приписывать слову „другой” исключительно солженицынские коннотации, то можно сказать, что Эткинд смотрит на описываемые им события изнутри мира, к которому он принадлежал по праву рождения и от которого никогда не отделял себя, но, как ему пришлось убедиться на собственном опыте и собственной судьбе, глазами „другого”.

\section{Литература}

Алексеева Л., 2012, История инакомыслия в СССР: новейший период. 3-е изд., Москва.

Белова О.В., 2002, „Другие” и „чужие”: представления об этнических соседях в славянской народной культуре, в: Признаковое пространство культуры, ред. С.М. Толстая, Москва.

Гензелева Р., 1999, Пути еврейского самосознания (Василий Гроссман, Израиль Меттер, Борис Ямпольский, Руфь Зернова), Москва-Иерусалим.

Дашевский В., Чернин В., Яглом В., 1989, Иудаизм в СССР, в: На пути к свободе совести, ред. М. Смирнов, Москва.

Долинин К., 2000, Впервые на франиузском языке, „Иностранная литература” бр. 6, с. $272-280$.

Козлов В.А., 2002, Крамола: инакомыслие в СССР во времена Н. Хрущева и Л. Брежнева (По материалам Верховного суда и Прокуратуры СССР). Статья 2, „Общественные науки и современность” бр. 4, с. 68-79.

Лурье С., 2001, O Барселонской прозе, в: Е.Г. Эткинд, Записки незаговорщика. Барселонская проза, Санкт-Петербург.

Маркиш Ш., 1997, Бабель и другие. 2-е репринтное издание, Москва-Иерусалим.

Проскурина В.Ю., 1992, Молодые годы Аарона Штейнберга, „Новое литературное обозрение" бр. 1, с. 236-238.

Фурман Д.Е., 1995, Массовое сознание российских евреев и антисемитизм, в: Уроки Холокоста и современная Россия, ред. М.Я. Гефтер, С.С. Неретина, Москва, c. $70-88$.

Эпштейн А., 2010, Русско-еврейские интеллектуалы первого советского поколения: итрихи к портрету, „Новое литературное обозрение” бр. 103, с. 86-108. Эткинд Е.Г., 2001, Записки незаговорщика. Барселонская проза, Санкт-Петербург. Юхнёва Н., 1999, Между традиционализмом и ассимиляиией (о феномене русского еврея), „Диаспоры” бр. 1, с. 160-178. 